\title{
When the Childhood Event Unfolds Itself: \\ On the Survivor's Guilt in The Kite Runner by Khaled Hosseini
}

\author{
Emily ShuHui Tsai \\ National Chung Hsing University, Taichung, Taiwan
}

\begin{abstract}
This short paper aims to discuss the unbearably-heavy weight of childhood memory and the survivor's guilt as the symptoms in the novel, The Kite Runner, published in 2003, by an Afghan-American writer, Khaled Hosseini. It describes the ambivalent relationship between the father and the son against the background of political turmoil in Afghanistan - how they have a good life together in Afghanistan and afterwards how they are forced to leave their homeland like refugees to Pakistan and then to The United States for a new life with the survivor's guilt after the tumultuous period of the Soviet military invasion. The narrator, Amir, treasures the memories of his old homeland, Afghanistan, the innermost remnants of his being, which has become as the specter haunting his present life in the United States. Amir has to return to his old homeland to meet his father's closest friend, Rahim Khan, and to rescue Sohrad, the son of his half-brother, Hassan, from the Taliban regime. This ethical return to the past not only has unfolded certain secrecy of his father's dishonor but also has healed his sense of survivor's guilt because of his evil rivalry of jealousy against Hassan to fully possess his father's love in his childhood. In my discussion of ethnic hierarchy and conflicts in Afghanistan described in the novel, Jacques Derrida's and Giorgio Agamben's theoretical concepts, such as the problematic of sovereignty, sovereign animality and bare life in The Beast \& the Soveriegn and Homo Sacer, will be used to penetrate the deeper understanding of their traumatic past as haunting specters.
\end{abstract}

Keywords: childhood memory, symptom, survivor's guilt, specter, bare life, sovereignty, animality

What is political sovereignty, the sovereign or the state or the people, figured sometimes as what rises, through the law of reason, above the beast, above the natural life of the animal, and sometimes as the manifestation of bestiality or human animality, i.e. human naturality?

(Derrida, The Beast \& the Sovereign, p. 26)

\section{Introduction}

Generally speaking, culture gradually develops itself by the collective mindset of the ethnic convention; the encounter with different cultures reveals respectively the cultural difference which somehow cannot be respected

Emily ShuHui Tsai, Associate Professor in the Department of Foreign Language and Literature, National Chung Hsing University, Taichung, Taiwan. 
equally but oftentimes can be mistakenly viewed (un)consciously only as superiority or interiority to the other different groups of people. The deep-rooted consciousness of hierarchy of the ethnic ideology somehow inevitably generates simmering envy or rivalries that may lead to violent riots or mass killing or even worse, genocide or ethnic cleansing, to justify what this group of people thinks their supreme good, which is, in fact, conversely, recognized as the supreme evil to others. This problematic consciousness is provoked by the aggression based on anxiety and insecurity of people when they are not recognized as superior to, or at least, as equal with the others. Under this crucial condition, I think that to stop the vicious rivalries out of jealousy is the collective repentance to sublimate the guilty conscience into the spiritually-elevated level of mutual respect or tolerance for the cultural difference.

The Kite Runner published in 2003 is written by an Afghan-American writer, Khaled Hosseini. It describes the ethnic conflicts, particularly focusing more on the ambivalent relationship between the father, Baba, and the sons, Amir and Hassan, against the background of political turmoil in Afghanistan: how they have a good life together in their country; how they are forced to leave their homeland like refugees to Pakistan and then to The United States for a new life with the survivor's guilt during the tumultuous period of the Soviet military invasion into Afghanistan; afterwards how the secrecy of the father's dishonor buried for his lifetime is revealed to the narrator, Amir, after his home-returning to Afghanistan to meet his father's closest friend, Rahim Khan and how Amir's survivor's guilt is gradually dissolved after rescuing his half-brother's son, Sohrad, back to the United States. As a stunning result of millions of copies being sold, this brilliant and touching novel has achieved an international success with critical acclaims and there have already appeared so far at least forty-two translated versions of different languages in thirty-eight countries.

As the title of the novel, The Kite Runner, has suggested, its theme is centered on an important character called Hassan, a Hazara boy, the best kite runner in Kabul. Although he is abandoned by his own mother, Sanauber, a seductive vision of male reveries of infidelity, who runs off with a nomadic clan of travelling singers and dancers after giving birth to Hassan, Hassan living with his foster father, Ali, under the protective umbrella of paternal love of Baba, is a very faithful servant and a brotherly companion to the narrator, Amir. In this novel, after Amir has escaped to the United States, Hassan has become a haunting image of childhood guilty memory that functions as a gravitational pull to force him with disgraceful remorse inescapably to confront his subtle evil of betrayal to Hassan: Amir sets up a cunning trap for Hassan to abandonment again by accusing him of stealing Baba's money and his watch. The consequence is that Ali, Hassan's foster-father, has decided to quit the house-serving job and move away with Hassan. If Amir hadn't done the fabricated accusation against Hassan because of jealous rivalry to possess Baba's full love, Ali and Hassan would have followed them to move to the United States and they would not have been killed by the Taliban regime of terror.

The deep-seated sense of guilt as a symptom which has plagued Amir (un)consciously for years is given a chance to be gradually dissolved after Rahim Khan, his Baba's long-term friend since childhood, calls him from Pakistan when he is ill and urges Amir to return "home" from the United States to solve some problems of the familial misfortune and to become "good" again. Otherwise, Amir would have carried this burdened symptom as a haunting specter for the rest of his life. As the childhood memory gradually unfolds itself together with the long-term buried traumatic events, Amir's confrontation with the past, on the one hand, compels him to accept who he really was, to atone for his sins, to nourish his compassion for Hassan and to face his father's unconcealed 
dishonor; on the other hand, he and his wife, Soraya, start to get involved in the Afghan projects to integrate himself more into his own ethnic identity and to atone for his sins that he used to bury in the memories of his original homeland.

\section{Animality and Sovereignty}

My idea of "animality" in this short paper does not deal with the natures of different species of animals but refer to the human condemnable enjoyment of cruelty, bestiality, apathy and indifference to others' suffering. "Animality" in humans is frequently discussed and analyzed in Freud's psychoanalytical works. Although Freud himself does not use this term "animality," he uses the other terms such as "aggression," "instincts," and "death drive" as these impulses are manifested in the criminal acts, like bully, torture, abuse, harassment, rape, mass killing, et cetera, without any consideration of the others' equal human right; Lacan also shares the same thought in his Seminar VII when he discusses sadism. To Freud, as he says in "Civilization and Its Discontents," humans are not gentle beings who out of impulses can become irrational and cruel to satisfy their aggression when they are attacked. To mock at the Christian teachings, such as "Love thy neighbor as thy neighbor loves thee," Freud continues to analyze that instincts are reversible, which means love turns into hate and hostility when the insatiable demand is not satisfied. Thus, the consequence is that this neighbor can be exploited without compensation, can be sexually violated and humiliated, and even worse, he can be tortured to death (Freud, 2001:110-111). In this condition, this is what I think the destructive forces of "animality" in humans.

Even in this post-ideological era of the contemporary post-human world, certain ideology can be still reinforced, particularly, the ethnic ideology of unity or community in the different territories. This ethnic ideology with its own morality empowers itself by excluding others if they do not accept the dominant rules. From this phenomenon, we can come to a sudden realization that the collective (un)consciousness of ethnic identity can not be easily transformed or reconstructed into a different level of mutual reciprocity to achieve a harmonious community because the mutual respect for the equal importance of cultural difference is posited as the global ideal, like Immanuel Kant's notion of transcendental idealism, eventually rendered itself as an illusion. Therefore, we can not expect more than the superficially-mutual tolerance for different cultures; if it can be maintained, the community in which different ethnic groups live is undeniably a good condition because the human inclination to the sense of superiority or inferiority to others is unavoidable. At the same time, the aggression constantly generates undercurrent grudges and complaints that may lead to conflicts. Thus, the problems of the purity of ethnic identities that empower a certain ethnic group by incurring violence can not be entirely avoided.

In this novel, to understand the traumatic events in Amir's and Hassan's childhood, perhaps, the kite-fighting tournament in winter for children is a good starting point for us to comprehend more about the internal ethic conflicts in Kabul, Afghanistan. Before it starts, Hassan, a Hazara boy, has been bullied several times by the Pashtun boy, Assef. Even the soldiers so openly like to brag about how they rape Hassan's mother near the creek when they encounter Hassan and Amir on the street. The Hazaras in this novel are identified as "mice-eating," "flat-nozed," "load-carrying donkeys" with the features of Mongoloid and they are frequently persecuted and oppressed by the Pashtuns (The Kite Runner 9-10). The damaged image of Hazaras as their socio-cultural sign of contempt undermines the dignity of Hassan because he bears the ethic sign of being a 
"Hazara". Assef, with the self-imposed superiority under this ideological umbrella of collective consciousness, always justifies himself to look for chances to bully Hassan and other boys as well. After the kite-fighting tournament, the best kite runner, Hassan, rushes to bring back the fallen kite as their honorable trophy with Amir; Assef and his teammates grab this chance to bully Hassan again by raping him when Hassan fails his fragile resistance. This is the jealous rivalry among the ethnic conflicts of teenagers because Assef takes it for granted that a Hazara boy should not have deserved to be treated as an equal and to have such an honor.

Thinking of the character, Assef, who functions as the ethnic threat and ideological assault to Hassan, the superiority of white supremacy still overshadows their collective consciousness among Afghan teenagers. Assef is described in this novel as a boy "born to a German mother and Afghan father, the blond, blue-eyed Assef towered over the other kids" (The Kite Runner 41); his "famous stainless-steel brass knuckles" a sign of masculinity, in fact, is his weapon to bully non-Pashtan boys. Wherever he and his teammates go, they create victimhood. Once Assef leading his teammates, Wali and Kamal, like a nazi Hitler, roars with resentment against Hassan, condemning him that Hazaras only belong to Hazarajat. Assef says: "Afghanistan is the land of Pashtuns. It always has been, always will be. We are the true Afghans, the pure Afghans, not this Flat-Nose here. His people pollute our homeland, our watan. They dirty our blood" (p. 44). Assef with his self-imposed leadership always thinks he is obliged to discipline non-Pashtan boys by threatening them to recognize Pashtans as the politically-right citizens in Afghanistan. Afterwards, Assef chides Amir for his Baba's employing Hassan and Ali, the Hazaras, to be their servants in the house, though Hassan tries to threaten Assef in return with his slinpshot too. Assef continues to roar that "You're part of the problem, Amir. If idiots like you and your father didn't take these people in, we'd be rid of them by now. They'd all just go rot in Hazarajat where they belong. You're a disgrace to Afghanistan (p. 45). The sense of superiority of privileging one ethic group over the other reveals the human animality of uncontrollable aggression against the others, which is fundamentally derived from the collective sense of guilt, fear and insecurity for their own survivorship in their territory.

The sense of guilt, interpreted by Freud in his essay "Civilization and Its Discontents" is the fear of losing the love and the protection of paternal authority in the society because our moral agent of the conscience, generally speaking, is gradually developed by its identification with the authority of powerful paternal figures. In the novel, it is obvious that if their deep-rooted ideology reinforces the hierarchy of ethnic identities, the children unconsciously affected by "this socio-cultural knowledge" would take advantage of it and justify their bullying those who are considered as "inferior" or "secondary." As such, on the one hand, they empower themselves to cover up their own weaknesses and to discharge anxiety of not being "truly" pure and superior; on the other hand, they feel "protected" in their own territory. After having penetrated into Assef's hidden weakness and his cruelty of bully, in fact, we know that he is not a "pure" Pashtan because he has a German mother. In addition, Pashtans fundamentally are Iranic ethnic group living in Pakistan and Afghanistan, whereas Hazaras are the native ethnic group living in the area of Hazarajat in central Afghanistan. Under his tormented struggle with the anxiety of occupying a certain territory to be a Hitler-like leader, this power-obsessed Assef shows his "authoritarian sovereignty" under the ideological umbrella of superior but insecure Pashtans, he bullies and victimizes other boys to cover up his own insecurity. The "supreme evil" in his moral conscience is mistakenly recognized by himself as his own "supreme good," demonstrating the sadistic desire of sovereign masculinity for his own survivorship. 
Freud thinks that the inherent aggression against others can be easily provoked when insecurity and anxiety of existence are devastatingly triggered. The idea of "the neighbor" may function perhaps sometimes as an object of prey for those with the self-imposed superiority to enjoy their pathologically-narcissistic desire as predators do their insatiable exploitation in whatever way.

The existence of this inclination to aggression, which we can detect in ourselves and justly assume to be present in others, is the factor which disturbs our relations with our neighbor and which forces civilization into such a high expenditure of energy. In consequence of this primary mutual hostility of human beings, civilized society is perpetually threatened with disintegration. The interest of work in common would not hold it together; instinctual passions are stronger than reasonable interests. (Freud, 2001: 112)

The mutual hostility of human aggression against their neighbors with apathetic cruelty is seriously examined when Freud studies the phenomenon of atrocities committed by the different ethnic groups against one another during the racial migrations.

Perhaps, drawing from this inference, we may think whoever possesses the power of sovereignty to set up the boundary of the ethnic community makes the decision to exclude the undesirable in the ethnic community as if some human lives can be discarded randomly without any legal protection. In Agamben's Homo Sacer, he describes two forms of lives: one is "zoē" which means "the simple fact of living common to all living beings (animals, men, or gods) and the other is "bios" which indicates "the form of way of living proper to an individual or a group" (Agamben, 1998: 1). In fact, all forms of lives on earth tend to be biopolitical, particularly, humans. Human different modes of lives are governed by the socio-cultural ethics of different social systems. The power of sovereignty creates the problem of bare life, which means that the life being banned in the state of exception determined by the politics of sovereignty is excluded within the ethnic community. This inclusive exclusion of bare life at the threshold should be reexamined by reconsidering the problematic biopolitics determined by the sovereign authoritarianism. Thinking of the powerful status of the sovereignty that determines the bare life outside the protection of the social law, the sovereign power itself related to the juridical order is a paradox because the sovereign is, at the same time, outside and inside the law.

The specification that the sovereign is "at the same time outside and inside the juridical order" is not insignificant: the sovereign, having the legal power to suspend the validity of the law, legally places himself outside the law. This means that the paradox can also be formulated this way: "the law is outside itself," or "I, the sovereign, who am outside the law, declare that there is nothing outside the law". (Agamben, 1998: 15)

To be more precise, within this theoretical framework, the sovereign is beyond the law because he is the decision-maker who makes the law. In other words, the sovereign law-speaker would not prescribe a law that could jeopardize the untouchable "nobility" of his or her own hierarchically-superior sovereign status.

Thinking of the disastrous event of ethnic cleansing described in the novel in Afghanistan, we feel appalled by their apathetic cruelty of the large-scale insurgency against their own people, randomly creating the inclusive exclusion of "bare life." Agamben's discussion of "the state of exception" is rather paradoxically controversial. The one who has the sovereign power is the decision-maker to condition the state of exception; the worsening problem is that there are many authority figures competing for the possession of the sovereignty to decide who should exist in the state of inclusive exclusion, namely, the state of exception. Given the circumstance, the sovereign, driven by the excessive desire fighting against the other sovereign power, is, in fact, the major element 
that creates disasters. Thus, we can draw an inference that atrocities, hostility, inequalities, disasters, or even worse, mass killings, or ethnic cleansing, are the evil consequences of the juridical law made by the biopolitics of the sovereign power that achieves nothing but the oppressed victims and refugees, who are inevitably forced to exist as the excluded mode of bare life.

Resonating with Agamben's concept of the sovereignty, Derrida goes further and argues in his book, The Beast \& the Sovereign, that the animal, the criminal, and the sovereign are ambiguously linked.

There is between sovereign, criminal, and beast a sort of obscure and fascinating complicity, or even a worrying mutual attraction, a worrying familiarity, an unheimlich, uncanny reciprocal haunting. Both of them, all three of them, the animal, the criminal, and the sovereign, are outside the law, at a distance from or above the laws: criminal, beast, and sovereign strangely resemble each other while seeming to be situated at the antipodes, at each other's antipodes. (Derrida, 2009: 17)

Derrida questions the heterogeneous ambiguity within the structure of the juridical law and thus the conventionally-believed righteousness of the sovereign power is undermined when it is inverted into its pathological enjoyment of narcissism obsessed exclusively with its own insatiable greed and benefits.

In the novel, Afghanistan not only has to confront their so-called Northern Alliance, the Soviet Union, with fear, but also has to face the deteriorating damages from the internal conflicts of its different ethnic power struggles. After the Taliban regime has driven away the Russian Alliance in 1996 from Kabul, Afghans' sense of emancipation from the exterior terror and appalling atrocities only stays for a while (The Kite Runner 215). The Taliban regime does not create for Afghans the good quality of life without gunfire and killings; they banned the kite-fighting tournament and "in 1998, they massacred the Hazaras in Mazar-i-Sharif" (The Kite Runner 230). After Rahim Khan had been to Hazarajat to look for Hassan and had invited Hassan and his wife, Farzana, to live with him in the old big mansion Amir's Baba had sold to him in Wazir Akbar Khan district in Kabul, one day Hassan was interrogated by the Talib officials striking into their house like "wolves looking at a flock of sheep" (The Kite Runner 236). This issue is that the Taliban does not allow the Hazaras to live in the big house in Wazir Akbar Khan in Kabul and thus they come to accuse the Hassans of being liars and shot them to death without any valid evidence. This cruel apathy directed to their own Afghans, though Hazaras are considered by them as inferior humans, oftentimes mistaken for the criminal acts of theft, is developed out of the ethnic ideology of collective symptoms. In addition, from how the death penalty — stoning the adulterers to death-is executed in the public square by the Taliban regime described in the novel, their rigid governance under the sovereign power reinforces the difference of their ethnic ethics of terror.

We are here today to carry out Shari'a. We are here today to carry out justice. We are here today because the will of Allah and the word of the Prophet Muhammad, peace be upon him, are alive and well here in Afghanistan, our beloved homeland. We listen to what God says and we obey because we are nothing but humble, powerless creatures before God's greatness... God says that every sinner must be punished in a manner befitting his sin. (The Kite Runner 292)

This ritual of death penalty carried out in public for the non-Muslims as a culture shock demonstrates the clearly-cut demarcation between the excluded bare life and the included civilians under the power of authoritarian 
sovereignty. The adulterers recognized here as "homo sacer"1 in this context are the appalling phenomenon because in other cultures, they may be regarded just as a disgrace or a dishonor, but they will not be stoned to death in public. The Islamic concept of "the sacred" (haram) means something in a state of impurity which is forbidden; a person who becomes the sacred man will be deprived of all legal rights and should be expelled from the society. Thinking of the extramarital affairs is a criminal act to the Muslims, it sheds some light on the issue that Amir's Baba has to cover up the secrecy of his "criminal guilt" of having sex with Sanaubar, Hassan's birth mother, in his lifetime. And as a Hazara woman, Sanaubar could not exist with the equal respect as a dignified woman to fulfill her own dream to achieve a good career because of exposing too much sexual attraction. Because of her disappearance for several decades, her sudden return to Hassan with the ravaged image of injured body deepens our compassion for her.

The rigid governance of biopolitics under the authoritarian sovereignty structures the society strictly as a battlefield of ethnic ideologies in which avengers and sinners ferret out more "sacred" men living in a mode of bare life. Animality in humans triggered by aggressors' threatening assaults or deadly attacks display both human weaknesses and wicked nature and thus render its social atmosphere brutally depressing. When Assef had a fierce fight against Amir who returned to Afghanistan to seek out Sohrab, Hassan's son, Assef told Amir how he once was for no reasons threatened to death and put in jail and how his kidney stones were forced out by the incessant leg-kicking attacks from the Taliban. Instead of violent resistance in return, Assef under a sudden epiphany of his "God" with a certain mission roared into ironic laughter. Several years later, Assef recognized that Tali commander in a battlefield again and he instantly killed him for the revenge of his deadly suffering in the cells. Amir retorted in a sarcastic tone that Assef's mission is nothing but stoning adulterers, raping children, flogging women for wearing high heels, massacring Hazaras, all in the name of Islam (The Kite Runner 307).

\section{Symptoms and Specters}

Each major character in this novel lives with his own symptom: to Amir, his betrayal to Hassan as his struggling ambivalence; to Amir's Baba, Hassan's birth as his guilty secrecy; to Hassan, the self-imposed inferiority and illiteracy as his dishonor; as to Assef, an excessive obsession with the sovereign power. To dissolve the symptoms, each of them has chosen his own "ethical act" to solve the problems although it might trigger evil out of excessive good that can induce some other unforgivable and traumatic events.

Generally speaking, flying the kite is enjoyable because it fulfills the dreams of human freedom that unburdens the temporary social obligations. When the kite is soaring into the blue sky, our mind is elevated into the aerial reveries of poetic daydreams. But on the contrary, if the entertaining kite-flying daydream becomes the kite-fighting tournament for the afghan boys, this playful game may turn out to be a battlefield of ethnic conflicts.

\footnotetext{
${ }^{1}$ In Agamben's book, Homo Sacer: Sovereign Power and Bare Life, it describes that in the archaic Roman law, the homo sacer is the sacred man who is guilty of committing crimes. Thus "the bad or impure man" is sacred. Anyone who kills the sacred man will not be considered as committing homicide and will not feel guilty or become convicted of any crime, according to the plebiscite. To be more precise, homo sacer is the sacred man who is condemned and banned from sacrifice in the religious ritual (Agamben, 1998:71-73). If nowadays, we search online Wikipedia for the concept of homo sacer, it explains the idea that a man who is cursed. The word, sacred, in Islamic notion, corresponds to their idea of "haram" which means "forbidden" and it also refers to "evil and sinful action" that is forbidden to be done. With this knowledge in Islamic context, the adulterers can be recognized as "homo sacer" in my paper here.
} 
The winter kite-fighting tournament ${ }^{2}$ in Kabul is the boys' war-like practice of masculine honor in their tradition: "In Kabul, fighting kites was a little like going to war" and "If the kite was the gun, then tar, the glass-coated cutting line, was the bullet in the chamber" (The Kite Runner 54). Amir's betrayal based on guilt lies in the fact that after his winning the kite-fighting tournament, Hassan, the best kite runner, is violently bullied and raped by Assef because of Hassan's refusal to give Assef the fallen kite as the trophy of honor which belongs to Amir. Amir only hides himself in the alley and bears witness to his own cowardice without rescuing "the poor lamb killed by the ferocious wolf." And he murmurs to himself that

I was afraid of Assef and what he would do to me. I was afraid of getting hurt. That's what I told myself as I turned my back to the alley, to Hassan. That's what I made myself believe. I actually aspired to cowardice, because the alternative, the real reason I was running, was that Assef was right: Nothing was free in this world. Maybe Hassan was the price I had to pay, the lamb I had to slay, to win Baba. Was it a fair price? The answer floated to my conscious mind before I could thwart it: He was just a Hazara, wasn't he? (The Kite Runner 84-85)

His cowardice tries to justify his betrayal to Hassan and thus his daily servant, almost like a close companion, is forced to become the victim of Assef's sexual assault. I wonder if Amir's Baba had revealed his guilty secrecy earlier to his two real sons and Amir had known that Hassan was actually his true brother, would Amir have acted in a different way?

Amir's Baba is highly respected in his homeland and there exists inevitably a jealous rivalry in Amir to possess Baba's full love; Hassan is eventually betrayed by what he has believed, that is, his loyalty to Amir. It has seldom occurred to Amir that what has been repressed will return to him in different ways; it is the return of the Real, in Lacanian sense, that strikes at Amir to force him to confront his own guilty conscience when he returns to Afghanistan to visit Rahim Khan who reveals the buried secrecy of his Baba's guilt and gives him the letters Hassan has written to him. This "truth" procedure of revealing the secrets of the past, to Amir, is an excruciatingly-mental ordeal, particularly to unfold the archives of traumatic memories and to learn the truth of his Baba's lies and dishonor.

The irony lies in the fact that truth, not simulation and lies, is his Baba's "true" teaching to him. Amir remembers once his Baba taught him that

But theft was the one unforgivable sin, the common denominator of all sins. When you kill a man, you steal a life. You steal his wife's right to a husband, rob his children of a father. When you tell a lie, you steal someone's right to the truth. When you cheat, you steal the right to fairness. There is no act more wretched than stealing. (The Kite Runner 115)

It is understandable for us to realize how agonizingly Baba's "guilty truth" when unconcealed strikes at Amir like a thunderbolt as a dark enlightenment after Rahim Khan has unfolded Baba's familial dishonor that Hassan is Baba's bastard son, Amir's half brother, and Hassan's birth mother is Sanaubar, a seductive Hazara woman with a questionable reputation. It is not easy for Amir to learn this familial dishonor from someone else without being heartbreakingly afflicted; when his Baba was alive, Amir was deprived of the right to know this ugly truth by his own Baba. On the other hand, Rahim Khan with compassion also tells Amir that the way his Baba redeems his

\footnotetext{
${ }^{2}$ In the novel, it describes that during the kite-fighting tournament, the real fun begins when the kite is cut and the most desired prize is the last fallen kite as the honorable trophy for the boys. Thus, to win the last fallen kite that can be displayed on a mantle for the visitors to the house is quite an honor not only for the boy who wins it but also for the family members who can be admired with a sense of pride (The Kite Runner 56-57).
} 
guilt is to feed the poor on the streets, build the orphanage, and give money to friends in need (The Kite Runner 326). Afterwards, Amir could understand why his Baba shared certain paternal love equally to Hassan and took him to receive a surgery on his hare-lips in the past.

Amir's return to his original homeland is "the truth procedure" of his promised atonement. With profound remorse, he has realized that he and his Baba have betrayed the people who would have given their lives for them. Amir with painful self-introspection thinks that

I had driven Hassan and Ali out of the house. Was it too far-fetched to imagine that things might have turned out differently if I hadn't? Maybe Baba would have brought them along to America. Maybe Hassan would have had a home of his own now, a job, a family, a life in a country where no one cared that he was a Hazara, where most people didn't even know what a Hazara was. (The Kite Runner 244)

When a decision has been wrongly made, there unexpectedly triggers its deadly-negative consequence one may never know what to do for a proper atonement to forgive oneself. After Amir has read Hassan's letters left to him, he is attacked again by his own survivor's guilt and at the same time touched deeply by Hassan's true loyalty and friendship. In one of the letters, Hassan writes:

Amir agha: Alas the Afghanistan of our youth is long dead. Kindness is gone from the land and you cannot escape the killings. Always the killings. In Kabul, fear is everywhere, in the streets, in the stadium, in the markets, it is a part of our lives here, Amir agha. The savages who rule our watan don't care about human decency...I wish you could see Sorab. He is a good boy. Rahim Khan sahib and I have taught him to read and write so he does not grow up stupid like his father...I dream that my son will grow up to be a good person, a free person, and an important person... I dream that someday you will return to Kabul to revisit the land of our childhood. If you do, you will find an old faithful friend waiting for you. (The Kite Runner 233-235)

To atone for his sins and to become "good" as Rahim Khan has held these wishes ${ }^{3}$ for Amir, what Amir can compensate Hassan for his own sins is to seek out where Hassan's son, Sorab, is in Afghanistan.

Amir with the help of Farid looks for Sorab into the orphanage governed by Zaman. From this hazardous journey, the encounter with hiw own power-corrupted culture, Amir's ambivalence with the survivor's guilt toward where he originally belongs can be hardly dissipated. In the first place, Amir is mocked at and misunderstood by Farid's sarcasm that he comes back to Afghanistan, like others, to sell the land, collect the money, run away like a mouse back to America and have a nice vacation with the family in Mexico (The Kite Runner 256). To the local Afghans, indeed, it is not easy to help those former citizens who did not stay to fight against the foreign invaders, the Russian Alliance. Given the circumstance, when Amir learns how Zaman runs the orphanage with the forced submission to the Taliban regime in an inhuman way, Amir has lost a certain status in the first place to justify his resentment with a roaring temper against him. Zaman, regarded by Amir as a

\footnotetext{
${ }^{3}$ Rahim Khan is also an important character in this novel. He functions as a bridge of compassion to bring Amir to walk on the road toward a proper atonement for both his sins and his Baba's guilt, so that afterwards, the power of empathy in Amir can be well-developed to accept who he truly was. After self-introspection, Amir could forgive his Baba's dishonor. On the way back to America after rescuing Sorab from Assef's sovereign guardianship, Amir reads the letter from Rahim Khan who writes that: "Amir jan, I know how hard your father was on you when you were growing up. I saw how you suffered and yearned for his affections, and my heart bled for you. But your father was a man torn between two halves, Amir jan: you and Hassan...what true redemption is when guilt leads to good...I know that in the end, God will forgive. He will forgive your father, me and you too. I hope you can do the same. Forgive your father if you can. Forgive me if you wish. But most important, forgive yourself...Y Your father, like you, was a tortured soul...We had both sinned and betrayed. But Baba had found a way to create good out of his remorse" (The Kite Runner 325-327).
} 
semi-children trafficker, complains the orphanage is the God-forsaken place and in fact he would have acted like others escaping to other foreign lands for a better life. Zaman with agony makes a confession:

I haven't been paid in over six months. I'm broke because I've spent my life's saving on this orphanage. Everything I ever owned or inherited I sold to run this godforsaken place. You think I don't have family in Pakistan and Iran? I could have run like everyone else. But I didn't. I stayed. I stayed because of them... If I deny him one child, he takes ten. So I let him take one and leave the judging to Allah. I swallow my pride and take his goddamn filthy...dirty money. Then I go to the bazaar and buy food for the children. (The Kite Runner 278)

Amir feels strongly affected by this pathetic condition: on the one hand, he does not come back to help organize the governance of orphanage with decency like his own Baba when he was still alive; on the other hand, he really becomes "a tourist" almost like a stranger in his original homeland, with his guilty mission only to seek out Sorab and bring him back to America.

Afterwards, more surprises arrive to appall Amir: Sorab is like a sexual captive, manipulated by Assef. The encounter with Assef again after so many years is another event of violent confrontation with humiliation. As previously discussed, Amir and Assef has a good fight before his rescuing Sorab from Assef's "indecent protection." By wrestling with Assef in order to "earn" Sorab back to America, Amir is eventually given a chance to fight against his impotent cowardice to exorcise the specter of his childhood guilt. A sudden epiphany occurs to Amir that he feels healed and thus he keeps laughing while Assef still keeps attacking him with his merciless fists. This good fight ends when Sorab uses the slingshot aiming at Assef's eye and injures him at the right spot and then Amir and Sorab can escape from Assef's sovereign hegemony. Another challenge awaiting him ahead is an unexpected event that Amir encounters with the iron-minded bureaucrat following Islamic law, Shari'a, which does not recognize adoption, and so Amir still has to struggle through this rigid regulation to win a visa to bring Sorab to America. Either Sorab should have the death certificate of his own parents because he has to prove he is an eligible orphan or Amir has to stay in Afghanistan if he wants to adopt Sorab as one of his family members. It seems that both of these choices the afghan bureaucrat forces them to choose one of them have already deprived them of a possibility of a new life. With help of Amir's several Afghan friends to help go through this complicated bureaucratic procedure, Amir eventually finds a way to get Sorab "a humanitarian visa" to America (The Kite Runner 369).

The past, not being evaporated or completely vanished, haunts like specters to preserve itself in the present toward the future: that is, the present is the bridge transporting the past toward the future. To Amir, thus, he feels a compelling force to redeem his debts of the past. As immigrants often feel compelled to fall into the unsettling conflicts of being partially excluded both from their original homeland and their new world, their anxiety of being inclusively-excluded wherever they go always marks them as "the others," as if they were living in the mode of "bare life." If Amir's childhood were not spent in Afghanistan but in America, perhaps, he would feel less obliged to return to atone for his sins. The childhood experiences as the archives of memories which function like the gravitational force imperceptibly to pull him back to the lost horizon, the unlocalizable center, in his (un)consciousness indeed can not be entirely buried and forgotten. The further he goes, the more the childhood memory exists like the string that pulls "the kite" back to where it belongs. Sorab has a hard time assimilating himself into the American culture and his long-term reticence which suggests he has been traumatized by his 
familial wounds deepens our empathy for him. Frequently, the immigrants fall into the disconcerting state of vacillating between nonidentity in the new world and the previous identity in his original homeland.

When it comes to the problem of redemption and forgiveness, the issue of the right to forgive is the most questionable because most of the time, particularly, the ordinary religious believers, may not differentiate the victims from the victimizers if they follow the vicious circle of reincarnation which means life itself is based on the governing vortex of causes and effects. As such, the suffering is unavoidable in life itself. What it means is that life is the duration of time haunted by the specters of the past, trapped in the metaphysical theater of familial tragedy partially oppressed by the collective (un)consciousness of its own ethnic ethics and partially determined by his own free choices. In this novel, after the disaster of September 11 attacks $^{4}$ in New York, by Islamic terrorists, "America bombed Afthanistan, the Northern Alliance moved in, and the Taliban scurried like rats into the caves"; surprisingly, Pashtuns, Tajiks, Uzbeks and Hasaras, these different ethnic groups in Afghanistan suddenly could gather in Bonn and they hope to "end over twenty years of unhappiness in their watan" (The Kite Runner 391-392). Amir, highly terrified, gets involved in the Afghan projects out of a sense of civil duty to help heal the Afghan refugees suffering from the land mine injuries in the hospital near the Afghan-Pakistani border. With this ethical act, Amir feels he can mitigate Sorab's weighty heaviness of being "displaced" in America as well as his own guilty self torn between the specter of the past and his new life in America.

Thinking of the survivor's guilt, one never knows how much one should do to entirely dissolve the symptom and eliminate this sense of guilt. If we tackle this issue from another perspective which is that Amir does not feel guilty and he shows indifference to his Baba's childhood friend, Rahim Khan, and also to people who suffer in Afghanistan, like so many other afghan immigrants, we, the readers, perhaps may not feel profoundly touched. On the other hand, if Amir is in full subjection to this survivor's guilt, including his own human right being violated, there is no limitation to uproot it and we would feel that Amir is stupid. As such, it creates a certain ethical controversy. The problem is that the atonement for his Baba's sins, haunted by "the paternal guilt" as a positive sign of filial devotion to his father, shows that he can be recognized as a good son in his afghan culture and also can be fully accepted by himself as a good man. In our contemporary understanding, this deep-seated notion still remains arguable that the child essentially does not need to "inherit" the familial heritage of "the paternal guilt," so that he does not have to become like another "King Oedipus." In Anti-Oedipus by Deleuze and Guattari, ${ }^{5}$ they think that "For the unconscious itself is no more structural than personal, it does not symbolize any more than it imagines or represents; it engineers, it is machinic. Neither imaginary nor symbolic, it is the Real in itself, the 'impossible real' and its production" (Deleuze and Guattari, 1977: 53). The multiple heterogeneity of

\footnotetext{
${ }^{4}$ On September 11, 2001, in New York, the Twin Towers of the World Trade Center were toppled down by the horrifying attacks of Islamic terrorists, Al-Qaeda. The two airplanes, American Airline Flight 11 and United Airlines Flight 175, were hijacked by an alliance of Islamic terrorists, led by Osama bin Laden and the hijacked airplanes were aimed at crushing the Twin Towers. This terrorists' attack killed 2,996 people and injured more than 6,000 people in New York. For further details, please read the Wikipedia: https://en.wikipedia.org/wiki/September_11_attacks.

5 The book, Anti-Oedipus by Deleuze and Guattari published in 1977 is an important theoretical work, which is often considered as a book responding to the political turmoil of May 1968 events in France (Buchanan 2008: 7). Deleuze and Guattari met each other after May'68 revolution to collaborate their theoretical book. When psychoanalysis focuses too much on the individual pathology, Deleuze and Guattari think otherwise, arguing that the rigid and unequal social regulation is the major oppressive factor that causes the individuals to fall into the unstable state of drastically-emotional swings. Anti-Oedipus, in other words, is to fight against the social oppression and to restructure the subject with the positive and new identity. This book has been regarded as a difficult book because its creative language is so unfamiliar and also the authors appropriate psychoanalytic terms to reexamine and to undermine certain misunderstanding of the unconscious creative energy by psychoanalysis.
} 
"constitutively-inclusive outside" in our subject, the so-called the Real (in Lacanian sense), the unconscious (in Freudian sense), or the forces of creative affects in the virtual (in Deleuze and Guattari's sense), is the unknown and the unnamable. This inclusively-excluded "unknown" level in different theoretical terminologies, structurally rooted as the constituted part of the self, known as "the fractured I," bears the secrecy of our immanence. Be it hauntology or ontology, we fundamentally can not return to "the origin," the pure form of time as difference, to recognize how this virtual otherness thinking in itself within the self gives rise to a series of empirical events that repeat in difference. Given the circumstance, the sense of guilt can be never entirely eliminated no matter how much one tries to do to feel less guilty to dissolve the symptom of "the debts." On the contrary, if the one who never feels guilty of certain unbearable sins or crimes, he would be defined as an unethical person in all cultures. To solve the problem of this aporia, instead of searching for the right way to decipher this impenetrably-ontological enigma within the fractured I, Amir tries to heal the wounds in his own way. It is an ethical act of love and self-respect not only for his Baba, but also, most importantly, for himself.

When Rahim Khan hopes that Amir should forgive his own Baba and also himself too, forgiveness itself has become an issue which can be hardly tackled with well. Derrida argues that forgiveness exists only when there is something unforgivable. If we forgive what appears forgivable, so-called "venial sin," the idea of forgiveness would disappear; "Forgiveness is not, it should not be, normal, normative, normalizing" (Derrida, 2001: 32). To be more precise, forgiveness should not be considered as an imposed obligation for the side of the victims. If it is, it is a moral perversity, particularly, when the event is aggravated to the irreparable and irredeemable disaster. For example, both Hassan and Sorab are the bullied victims of the sexual assaults by Assef. Hassan does not turn out to be a raging avenger to fight against Assef though he could do so. Compassion is Hassan's way of dealing with conflicts, from which Amir seems to be unable to accept it until eventually the moment when Amir himself has a good fight against Assef, because Amir recalls the pomegranate event with Hassan in their childhood. Amir throws pomegranates consecutively to hurt Hassan and wants him to pick up the fruit to hit him back after Hassan has been sexually violated by Assef. Hassan simply takes one pomegranate and crushes it on his forehead and says: “Are you satisfied now? Do you feel better?" and then he walks away (The Kite Runner 312). Because Assef also does suffer from the Taliban regime, otherwise, Amir could really kill him during that good fight. The problem is that Hassan's compassion is not used in a wise way and as such, Assef's traumatic "wounds" could be transferred to sexually manipulate Sorab to empower himself and to cover up his sense of guilt. Assef's supreme "evil" is recognized mistakenly by himself for his supreme "good": a behavioral form of inverse or perverse ethics. From the perspective of psychoanalysis, this is the pathological authoritarianism driven by the ideal-seeking but sadomasochistic death drive merely for a narcissistic self-survivorship, because it creates damages and victimhood without any consideration of the human right.

Thinking of the two political events-Taliban regime's ethnic cleansing, massacring Hazaras, in Afghanistan, after it has driven away the hostile Russian Alliance back to the North and September 11 attacks in New York by Islamic terrorists although these are not the main focus of this novel, we would fall into a disconcerted state of complete silence because, apparently, the events seem to be incurred by the vicious circles of "the paternal guilt" inherited by "the sons" and thus the burning animosity of their mutually-uncompromising conflicts can hardly come to a certain reconciliation. When the severe and bloody conflicts cause too many casualties, the ethical impasse will occur because it is abnormal to normalize the condition with a moral demand 
that the victimizers should just give an official apology and offer some financial fine as compensation. Its central aporia lies in the fact that to a certain ethnic ideology, something remains unexchangeable, that is, there is no equivalence of the same values between two objects. Derrida argues that there exists the imprescriptibility of "the crimes against humanity." Therefore, when there occurs in a large-scale the terror-attacks or massacres or even ethnic cleansings, particularly, which cause the death of "innocent people," it is an impossibility to forgive the unforgivable and the series of its consequential outbreak of violence will never arrive at a complete stop.

Obviously, forgiveness exists only when there is something unforgivable and so it makes the ethical act of forgiveness more meaningful if it is derived from the purity of forgiveness without the involvement of sovereign politics. By the same token, Derrida thinks that

What makes the "I forgive you" sometimes unbearable or odious, even obscene, is the affirmation of sovereignty. It is often addressed from the top down, it confirms its own freedom or assumes for itself the power of forgiving, be it as victim or in the name of the victim. However, it is also necessary to think about an absolute victimization which deprives the victim of life, or the right to speak, or that freedom, that force and that power which authorizes, which permits the accession to the position of "I forgive". (Derrida, 2001: 58-59)

Following this theoretical inference, it is unforgivable to deprive the victims of the human right to speak for himself as well as an imposed obligation from the supreme demand of the sovereign politics to coerce the victims to forgive the unforgivable. Therefore, Derrida dreams that if the purity of forgiveness is worthy of its name, it would be "a forgiveness without power: unconditional but without sovereignty" (Derrida, 2001: 59). As to this ideal condition, it is apparently the most difficult task. This novel ends with the scene that Amir and Sorab enjoy the kite-fighting game again in the park in America, as Amir murmurs to himself: "I ran. A grown man running with a swarm of screaming children. But I didn't care. I ran with the wind blowing in my face, and a smile as wide as the Valley of Panjsher on my lips. I ran" (The Kite Runner 401).

\section{Conclusion}

To conclude briefly, The Kite Runner is a wonderfully-touching novel with its multi-layered complexity of the ethnic conflicts to draw the readers' attention to penetrate deeper into the socio-cultural texture of the miesrable land of Afghanistan as well as to solve the mystery that has always misguided people to picture all Muslims in our mind the negative image as if they were all the terror-makers. With the central theme, atonement and the survivor's guilt, we are affected by their struggling sentiment that to atone for the sins is to liberate oneself from the traumatic wound of the past with the courage of inner truth, which is not so easy for humans, particularly, in the world in which evil seems to be allowed to exist in the first place. When people constantly bear witness to the existence of "the banality of evil," they would feel less affected by the evil of violent events. However, on the other hand, the good moral conscience of people still exists; repentance and redemption will be unconcealed when their mind is more enlightened again.

Alain Badiou discusses the three figures of evil in his book, Ethics, such as infidelity or betrayal, simulacrum and the forcing the name of the unnamable (Badiou, 2001: 87), particularly the third based on the sovereign power with the perverse or inverse reason, which is the different order of problematic ethics, creating the unforgivably-evil events against humanity. In the novel, we understand how the vicious power struggle is triggered by envy, leading to passionate aggression, violent riots, crimes and disasters beyond our imagination. 
Evil is provoked by the excess of the Good; the excessive protection of one's good will inevitably breed evil and generate violent riots. It seems to be the vicious repetition of traumatic history in all cultures as the human condition. But once the tormented sense of guilt is afflicted too much by the self-punishing conscience, people either justify their crimes or try to do something good in return as compensation to heal their inner wounds. In this novel, we understand that to be good or evil is decided by our own free choice and self-discipline. The problem lies in the fact that people should not take it for granted that to demand forgiveness from the side of the victims is normal, because the victimizers will not feel guilty once forgiveness is normalized. As Derrida argues that "the imprescriptibility of the crimes against humanity" should exist, I think that all evil acts violating one single human right should not be considered afterwards as something forgivable. Therefore, humans have to regulate and discipline well "the violent impulses of animality" existing in the aggressive death drive which always fantasizes too much with their own "untouchable" sovereign power to totally dominate and to possess what should belong to them.

\section{References}

Agamben, Giorgio. Homo Sacer: Sovereign Power and Bare Life. Trans. Daniel Heller-Roazen. Stanford: Stanford UP, 1998. ---. The Coming Community. Trans. Michael Hardt. Minneapolis: U of Minnesota P, 1993.

Badiou, Alain. Ethics: An essay on the Understanding of Evil. Trans. Peter Hallward. London: Verso, 2001.

Buchanan, Ian. Deleuze and Guattari's Anti-Oedipus: A Reader's Guide. New York: Continuum, 2008.

Deleuze, Gilles and Félix Guattari. Anti-Oedipus: Capitalism and Schizophrenia. Trans. Robert Hurley, Mark Seem, and Helen Lane. New York: The Viking, 1977.

---. Proust and Signs. Trans. Richard Howard. New York: George Braziller, 1972.

Derrida, Jacques. The Beast \& the Sovereign (Vol.1). Eds.Michel Lisse,Marie-Louise Mallet, and Ginette Michaud. Trans.Geoffrey Bennington. Chicago: U of Chicago P, 2009.

---. On Cosmopolitanism and Forgiveness. Trans. Mark Dooley and Michael Hughes. London: Routledge, 2001.

---. Archive Fever: A Freudian Impression. Trans. Eric Prenowitz. Chicago: U of Chicago P, 1995.

Foucault, Michel. The Courage of Truth. Ed. Frédéric Gros. Trans.Graham Burchell. New York: Palgrave Macmillan, 2012.

Freud, Sigmund. "Civilization and Its Discontents." The Standard Edition of the Complete Psychological Works of Sigmund Freud (Vol. XXI (1927-1931), pp. 64-145). Trans. James Strachey. London: Vintage, 2001.

Hosseini, Khaled. The Kite Runner. New York: Riverhead Books, 2003. 